\title{
Rasa Humor dalam Perspektif Agama
}

\author{
Iwan Marwan ${ }^{1}$
}

\begin{abstract}
Abstrak
Tak diragukan lagi bahwa humor itu ada dalam khasanah agama islam. Kisah Nabi dan para sahabatnya menunjukan bahwa humor dan anekdot itu ada, yang secara eksplisit muncul dalam konteks al-Quran dan hadits. Islam tidak pernah melarang tertawa, bahkan berusaha mengelola dan membatasi tertawa sebagai sebuah bentuk kebahagiaan saja, bukan keterlenaan terhadap kenikmatan duniawi. Artikel ini mencoba membahas tertawa, lelucon dan humor dalam sudut pandang Islam. Pembahasan topik tersebut dibagi ke dalam empat bahasan. Pertama, rasa humor itu sendiri yang meliputi fenomena humor dan teori humor. Kedua, jenisjenis humor dalam al-Quran dan Hadits. Ketiga, etika humor dan fungsi humor. Keempat, hubungan antara humor dan agama. Hasil dari pembahasan menunjukan bahwa selera humor adalah sebuah anugerah dari Tuhan. Menciptakan humor atau sesuatu yang lucu untuk membuat orang lain bahagia adalah sebuah ide yang baik. Walaupun begitu, agama tetap mengingatkan agar tidak melupakan kehidupan akhirat dan kebahagiaan di sana yang abadi. Manusia dapat meraih kebahagiaan di akhirat dengan berupaya membatasi tertawa dan humor agar tidak berlebihan.
\end{abstract}

Kata kunci: Selera humor, humor dalam quran dan hadits, hubungan humor dan agama

\begin{abstract}
No doubt exists that humor is present in religion (Islam). On the stories nabi and sahabat showed there are humor and anecdot used in Islam as it is on the holy Qur'an and hadits explicitly. Islam instead of prohibits, manages and restricts laugh as expression of happiness in order to preserve people from preoccupation of wordliness.The article discuses laugh, jokes or humor in Islamic point of view. The discussion divided into four sub discussions. First, sense of humor which included humor phenomenologic and humor theories. Second, humor verses on holy Qur'an and hadists. Third,humor ethics and humor function. Fourth, relations between humor and religion. Result of the discussion showed that sense of humor is a gift from God. Creating joke or funny thing to make people happy is a good deed. Religion put one in mind of not forgeting life after death and happiness on it. People can reach happiness in the hereafter by stinted laugh or jokes.
\end{abstract}

Keywords: Humor sense, humor in Quran and hadits, relation between humor and religion

\footnotetext{
${ }^{1}$ Sekolah Tinggi Agama Islam Negeri (STAIN) Kediri
} 


\section{Latar belakang}

Humor sebagai bagian dari kualitas insani memiliki dampak positif bagi kesehatan fisik dan mental manusia. Banyak temuan penelitian yang membuktikan manfaat humor. Humor dapat mengurangi tingkat kecemasan dan stres individu, meningkatkan kesehatan mental, serta berkaitan erat dengan kreativitas dan kepribadian matang. Perhatian ahli-ahli ilmu sosial, khususnya psikologi, terhadap fenomena humor ternyata juga cukup besar. Terlihat dengan adanya berbagai teori dan penelitian tentang humor dalam kaitannya dengan kehidupan manusia. Termasuk penelitian mengenai pengembangan alat ukur rasa humor guna menelusuri tingkat dan jenis rasa humor yang terdapat pada individu. Salah satu penelitian yang berkaitan dengan alat ukur rasa humor ini adalah penelitian Thorson \& Powell, ${ }^{2}$ yang mencoba menggabungkan berbagai konsep dan definisi rasa humor dari penelitian terdahulu, sehingga dihasilkan konsep yang multidimensional dalam memaknai rasa humor.

Humor sangat penting dalam kehidupan manusia, karena humor memicu seseorang untuk tersenyum dan tertawa. Senyum dan tawa sangat bermanfaat untuk kesehatan jiwa manusia. Amin berkata, "seandainya manusia bersikap jujur, niscaya mereka tidak memerlukan tiga perempat obatobatan yang ada di apotik, dan ia cukup mengobatinya dengan tertawa. Satu tawa lebih baik dari seribu kali aspirin dan pil penenang. ${ }^{3}$ Orang yang banyak tersenyum akan melihat kesulitan-kesulitan hidup dengan tenang, untuk kemudian

${ }^{2}$ Thorson \& Powell dalam Martin, R. Sense of Humor. In S. J. \& C.R. Snyder (Eds) Positive Psychological Asssesment. A Handbook of Models and Measures. (American Psychological Association, Washington DC: 2003) Hlm. 313326.

${ }^{3}$ Al-Qarni , 'Aidh. Ibtasim. (Riyadh: Maktabah 'Ubaikan, 2005) hal. 10 mampu mengalahkan kesulitan-kesulitan itu.

\section{Sense Humor (rasa humor)}

Sebelum menjelaskan sense of humor, perlu diketahui defenisi humor. Suyasa menjelaskan bahwa berdasarkan telaah teoretis mengenai humor definisi humor dapat dibagi menjadi tiga, yaitu (a) humor sebagai stimulus (humor stimulus), (b) humor sebagai respon (sense of humor), dan (c) humor sebagai istilah. Humor sebagi stimulus dapat diartikan bahwa humor objek (katakata/perilaku dalam bentuk audio dan visual), baik dalam bentuk konkret maupun imajinasi (abstrak) yang berpotensi menimbulkan perilaku tersenyum atau tertawa. Humor sebagai respon, artinya humor adalah kecenderungan individu untuk bersikap positif pada lingkungan maupun individu lain, dengan menampilkan perilaku tersenyum dan tertawa. Ia menyimpulkan defenisi ini sebagai keenderungan individu untuk tampil ceria atau dengan kata lain disebut juga tingkat keceriaan individu. Humor sebagai istilah, sebagaimana dikatakan Martin $^{4}$ artinya istilah untuk mendefinisikan perilaku tersenyum atau tertawa yang terjadi karena hal positif. Perilaku tertawa yang terjadi karena hal negatif, misalnya meledek, merendahkan orang lain, menggoda adalah bukan humor.

Adapun menurut Thorson \& Powell ,5 sense of humor itu sifatnya multidimensional, dan oleh sebab itu maka minimal harus terdiri dari elemen-elemen berikut:

(1) Humor production, berupa kemampuan kreatif menjadi humoris,

${ }^{4}$ R. Martin.. Sense of Humor. In S. J. \& C.R. Snyder (Eds) Positive Psychological. 2003

${ }^{5}$ Thorson \& Powell dalam Martin, R. Sense of Humor. In S. J. \& C.R. Snyder (Eds) Positive Psychological Asssesment. A Handbook of Models and Measures. (American Psychological Association, Washington DC: 2003) Hlm. 313326. 
membuat lelucon, mengidentifikasi hal yang lucu dalam sebuah situasi serta mengkreasikan dan menghubungkan situasi tersebut dengan cara-cara yang dapat menyenangkan orang lain,

(2) Sense of playfulness, yakni kemampuan berada dalam kondisi yang senantiasa baik, menyenangkan, in a good mood,

(3) Kemampuan menggunakan humor dalam hubungan sosial (Social Uses of Humor): meredakan situasi sosial yang tegang atau kaku, meningkatkan solidaritas dalam kelompok,

(4) Personal Recognition of Humor, berupa penggunaan humor dalam memandang hidup dan melihat diri sendiri sebagai orang yang humoris,

(5) Appreciation of Humor, berupa apresiasi terhadap orang-orang yang humoris dan situasi yang penuh humor,

(6) Penggunaan humor sebagai mekanisme dalam beradaptasi, yakni kemampuan "mentertawakan situasi" atau mengatasi situasi sulit dengan menggunakan humor.

\section{Beberapa Pendekatan terhadap Humor}

Mindess berpendapat bahwa fungsi humor yang paling penting dan paling fundamental adalah kekuatannya untuk membebaskan diri dari banyak rintangan dan pembatasan dalam kehi-dupan sehari-hari. Humor dapat melepaskan individu dari berbagai tuntutan yang dialami. Humor juga dapat membebaskan individu dari perasaan inferioritas (perasaan tidak berarti yang sangat kuat dan tidak disadari). Keyakinan pada pentingnya humor untuk kesehatan mental khususnya yang baik, tampaknya diakibatkan dari pengalaman umum banyak orang bahwa humor sering dapat mengangkat individu dari cengkraman depresi atau keadaan mental yang negatif. Penelitian yang sudah dilakukan oleh $\mathrm{O}^{\text {ee }}$ Connell mendukung pandangan bahwa humor secara positif berkaitan dengan adjust-ment (penyesuaian diri) yang sehat. Tingkat penghargaan terhadap humor seseorang secara positif berkorelasi dengan tolak ukur psikologis atau kematangan dan memiliki karakteristik kepribadian yang stabil (dalam Soetedjo, 1999)

Seseorang yang memiliki rasa humor (sense of humor) yang baik dapat terbentuk berdasarkan beberapa pendekatan tentang humor, yaitu:

a. Pendekatan Kognitif, menurut O Connell (dalam Soetedjo, 1999), humor memilki aspek perseptualkognitif. Penemuan melalui kaidah kognitif menyebabkan bagian yang ganjil dari lelucon itu dapat diterima dan dianggap masuk akal, meskipun masih melanggar pengharapan individu. Dengan kata lain, penciptaan humor melibatkan elaborasi dari situasi yang nampaknya normal dan masuk akal tetapi ditumbangkan oleh analogi dan penyimpangan dari yang biasa (Munandar, 1996). Lebih lanjut Martin dan Lefcourt (dalam Soetedjo, 1999) menjelaskan bahwa berpikir humoristik sama dengan cara berpikir yang kreatif, karena harus menerjemahkan hal-hal wajar (normal) menjadi sesuatu yang menghasilkan refleks fisiologis yaitu tertawa. Oleh karena itu, humor dianggap sebagai bagian dari aktivitas kreatif, selain penemuan ilmiah dan karya seni. Pada saat mengapresiasi humor terdapat faktor ketakterdugaan, yang terjadi pada saat apa yang diharapkan ternyata digantikan oleh sesuatu yang sepele, atau ketakterdugaan yang masuk akal yang bersifat tiba-tiba dan tidak diperkirakan sebelumnya. Salah satu contohnya adalah iklan Nescafe versi Dona yang sering ditayangkan di televisi dan media cetak. Adanya faktor ketakterdugaan menempelnya ampas kopi di gigi seseorang gadis cantik, menimbulkan reflek tertawa orang yang melihatnya. 
b. Pendekatan Psikologis, humor efektif untuk membantu seseorang menghadapi kesukaran. Shehy (dalam Munandar, 1996) menemukan bahwa kemampuan untuk melihat humor dalam situasi merupakan salah satu cara yang dapat digunakan untuk mengatasi krisis hidup, yaitu sebagai perlindungan terhadap perubahan dan ketidaktentuan. Humor dianggap sebagai alat yang efektif untuk mencapai status (Nilsen, 1993). Seseorang tertawa disebabkan secara tiba-tiba menyadari bahwa dirinya superior atau orang lain inferior dan menurut Martin dan Lefcourt humor juga dapat menjadi strategi coping yang adapatif (dalam Soetedjo, 1999), karena itu humor oleh Freud dianggap sebagai proses pertahanan diri yang tertinggi.

c. Pendekatan Fisiologis, hasil penelitian Lefcourt (2005) menunjukkan bahwa humor berhubungan dengan meningkatnya tingkat konsentrasi S-IgA, yaitu salah satu sistem kekebalan tubuh. Adam (dalam Rachmaningrum, 1999) mengatakan bahwa secara fisiologis, humor membentuk dasar kesehatan mental yang baik. Ketiadaan sense of humor pada diri individu mengindikasikan adanya masalah, seperti depresi atau keterasingan diri. -Humor adalah alat penangkal stress dan sarana untuk memperlancar penyaluran-penyaluran naluriah yang baik. Humor juga dipercaya sebagai hal yang penting dalam penyelesaian masalah individual, komunitas, dan masyarakat.

d. Pendekatan Pendidikan dan Sosial, pendapat Nilsen (1993) bahwa humor sebagai pendidikan, humor dan tertawa menyebabkan seseorang lebih waspada, otak digunakan, dan mata bersinar. Humor dan tertawa merupakan alat belajar yang penting. Selain itu, merupakan alat yang sangat efektif untuk membawa seseorang agar mendengarkan pembicaraan dan alat persuasi yang baik. Sedangkan sebagai sosial, humor bukan saja dapat digunakan untuk mengikat individu atau kelompok yang disukai, tetapi juga dapat menjauhkan diri dari individu atau kelompok yang tidak disukai.

\section{Teori-Teori Humor}

Humor banyak dianalisis melalui teori-teori psikologi. Dalam teori psikologi ada tiga kubu yang berpengaruh dalam humor, yaitu teori pembebasan, teori konflik, dan teori ketidakselarasan (Wilson, 1979: 10)

Teori pembebasan (suppression/repression) merupakan penjelasan dari sudut dampak emosional, yakni bahwa humor akan membebaskan seseorang dari perasaan tertekan secara psikologis dan termarginalisasikan secara sosial (Wilson, 1979:10). Lelucon tidak lain adalah tipu daya emosional yang kelihatan seoalah-olah mengancam, tetapi terbukti tidak ada apa-apanya.

Teori konflik (conflict theory-socialbehavioral) memberikan tekanan pada implikasi perilaku humor, yaitu konflik antara dua dorongan yang saling bertentangan. Greig (Wilson, 1979:11) mengatakan bahwa humor sebagai pertentangan antara keramahan dan kebengisan. Menurut Knox (Wilson, 1979) petentangan itu terwujud antara main-main dan keseriusan. Selain itu, Witterstein (Wilson, 1979) menyatakan humor sebagai benturan antara 'mania' (antusiame yang berlebihan) dan "depresi" (kemurungan, kesedihan). Humor dianggap sebagai penjajaran dua atau lebih situasi yang bertentangan ke dalam satu konteks.

Teori ketidakselarasan (cognitiveperceptual), menurut Wilson (1979) merujuk pada penjelasan kognitif, yaitu dua makna atau interpretasi yang tidak sama digabungkan dalam satu makna gabungan yang kompleks. Dalam pikiran orang ditanya sekaligus masuk dua 
makna yang berlawanan, tetapi mengacu pada satu hal yang sama. Menurut teori ini, humor secara tidak kongruen menyatukan dua makna atau penafsiran yang berbeda ke dalam suatu objek yang kompleks. Ketidaksejajaran atau ketidaksesuaian bagian-bagian itu dipersepsikan secara tiba-tiba oleh penikmatnya.

\section{Ayat-Ayat Rasa Humor}

Apakah Anda termasuk orang yang suka bercanda? Ataukah Anda adalah orang yang sangat serius dan tidak suka bercanda? Apakah Anda termasuk orang yang banyak tertawa? Ataukah Anda termasuk orang yang tidak sering tertawa? Manusia diciptakan oleh Allah dengan berbagai watak dan perilaku. Kita tidak bisa menyalahkan sepenuhnya orang yang memiliki watak demikian. Karena tertawa adalah fitrah manusia, yang tidak diberikan kepada hewan. Apakah pembaca pernah mendapatkan hewan yang tertawa? Jujur saja penulis sendiri belum pernah mendapatkannya. Mungkin, kalau pun ada itu hanya terjadi pada momen-momen tertentu dan sangat jarang sekali.

\section{Al Quran menyoal rasa humor}

Sebagai pedoman dan panduan hidup manusia, Al Quran telah menjelaskan petunjuk yang utuh dan lurus dalam menyingkap rahasia-rahasia kesemestaan, baik secara ekplisit maupun implisit. Bagi pembacanya, kalamullah tersebut memiliki efek psikologis, yakni dorongan untuk terus melakukan pendekatan jiwa, penyatuan dan penyerahan diri, efek sosiologis, yakni hasrat dan motivasi untuk berinteraksi dan berbagi pada sesama, serta efek spiritual, yakni dorongan untuk meningkatkan amal ibadah dan meraih pahala kenikmatan yang melimpah.

Dengan demikian, Al Quran mengisyaratkan agar manusia berpikir cerdas dan kritis, bertindak kreatif untuk menemukan keagungan Tuhan melalui
ayat-ayat-Nya (kauniyah dan qauliyah). Terkait dengan hal tersebut, Al Quran menyebutkan tentang tawa dan senyum.

$$
\text { كلنيضحكو ا قليلا وليكو ا كثير ا جز اء بما }
$$

Maka hendaklah mereka tertawa sedikit dan menangis banyak, sebagai pembalasan dari apa yang selalu mereka kerjakan. At Taubah: 82

$$
\begin{aligned}
& \text { فتبسم ضاحكا من قولها وقال رب اوزعنى ان ان أن الدي }
\end{aligned}
$$

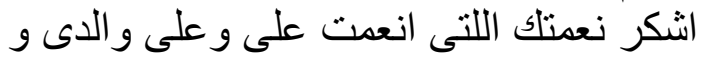

$$
\begin{aligned}
& \text { ان اعمل صالحا ترضاه و ادخلني برحمتلك في التياتي } \\
& \text { عبادك الصالحين }
\end{aligned}
$$

Maka dia tersenyum dengan tertawa karena (mendengar) perkataan semut itu. Dan dia berdoa: "Ya Tuhanku berilah aku ilham untuk tetap mensyukuri nikmat Mu yang telah Engkau anugerahkan kepadaku dan kepada dua orang ibu bapakku dan untuk mengerjakan amal saleh yang Engkau ridhai; dan masukkanlah aku dengan rahmat-Mu ke dalam golongan hamba-hamba-Mu yang saleh.(An Naml: 19)

$$
\text { وانه هو اضحك وابكى }
$$

Dan bahwasanya Dialah yang menjadikan orang tertawa dan menangis, (An Najm: 43).

$$
\text { ضاحكة مستبشرة }
$$

tertawa dan bergembira ria (Abbasa: 39).

$$
\text { ور آر أته قائمة فضحقت فيشر نهاب بإسحق ومن }
$$

Dan isterinya berdiri (dibalik tirai) lalu dia tersenyum, maka Kami sampaikan kepadanya berita gembira tentang (kelahiran) Ishak dan dari Ishak (akan lahir puteranya) Ya'qub. (Hud:71).

Lima ayat Al Quran di atas menjelaskan bahwa rasa senyum dan tawa adalah rasa yang dianugrahkan Allah swt kepada manusia. Senyum sebagai ungkapan kegembiraan atau kebahagiaan yang dirasakan oleh manusia. Namun demikian Al Quran tidak memperbolehkan tertawa secara berlebihan. 


\section{Hadis menyoal rasa humor}

Rasulullah shallallahu 'alaihi wa sallam pernah memberikan beberapa nasihat kepada Abu Hurairah radhiallahu 'anhu, di antara nasihat tersebut adalah perkataan beliau:

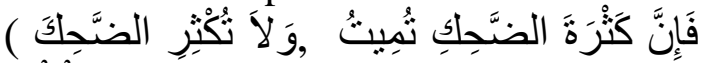

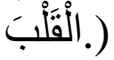

"Janganlah banyak tertawa! Sesungguhnya banyak tertawa akan mematikan hati."1

Apakah Rasulullah shallallahu 'alaihi wa sallam tidak pernah tertawa? Rasulullah shallallahu 'alaihi wa sallam pernah tertawa. Banyak hadits yang menunjukkan hal tersebut, di antaranya adalah yang diriwayatkan oleh Abdullah bin Mas'ud radhiallahu 'anhu dalam haditsqudsi yang panjang, Allah ta'ala berkata kepada anak adam:

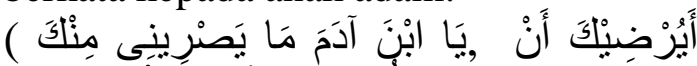

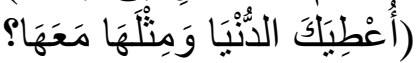

"Wahai anak adam! Saya tidak akan menghalangi apa yang engkau inginkan. Apakah engkau ridha jika saya berikan kepada engkau dunia dan ditambah dengan yang semisalnya? "

Anak Adam itu pun berkata:

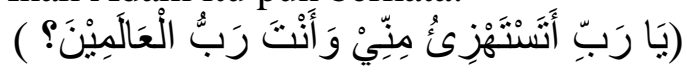

"Wahai Rabb-ku! Apakah Engkau mengejekku, sedangkan Engkau adalah Rabb alam semesta?"

Kemudian Ibnu Mas'ud pun tertawa dan berkata, "Mengapa kalian tidak bertanya kepadaku, mengapa aku tertawa?" Murid-murid Ibnu Mas'ud pun bertanya, "Mengapa engkau tertawa?" Beliau menjawab, "Seperti inilah Rasulullah shallallahu 'alaihi wa sallam tertawa. Para sahabat pun bertanya kepada Rasulullah, 'Mengapa engkau tertawa, ya Rasulullah?' Beliau pun menjawab:

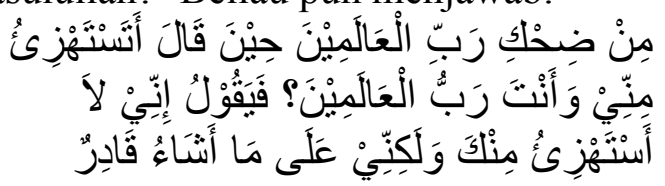

'Karena tawanya Rabb alam semesta ketika dia (anak adam) berkata: Apakah Engkau mengejekku sedangkan Engkau adalah Rabb alam semesta?' Kemudian Allah berkata, 'Sesungguhnya Aku tidak mengejekmu, tetapi semua yang Aku inginkan Aku mampu. '."

Rasulullah shallallahu 'alaihi wa sallam pada hadits di atas melarang seseorang untuk banyak tertawa dan bukan melarang seseorang untuk tertawa. Tertawa yang banyak dan berlebihlebihanlah dan mengandung celaan yang tidak diperbolehkan.

Rasulullah shallallahu 'alaihi wa sallam juga pernah bercanda. Sebagaimana yang diriwayatkan oleh Abu Hurairah radhiallahu 'anhu, para sahabat pernah berkata kepada Rasulullah shallallahu 'alaihi wa sallam

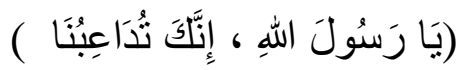

"Ya Rasulullah! Sesungguhnya engkau sering mencandai kami."

Beliau pun berkata:

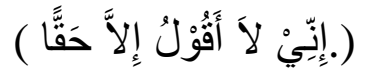

"Sesungguhnya saya tidaklah berkata kecuali yang haq (benar)."

Di antara canda-canda Rasulullah shallallahu 'alaihi wa sallam tercantum pada dua hadits berikut:

\section{$\underline{\text { Hadits } 1}$}

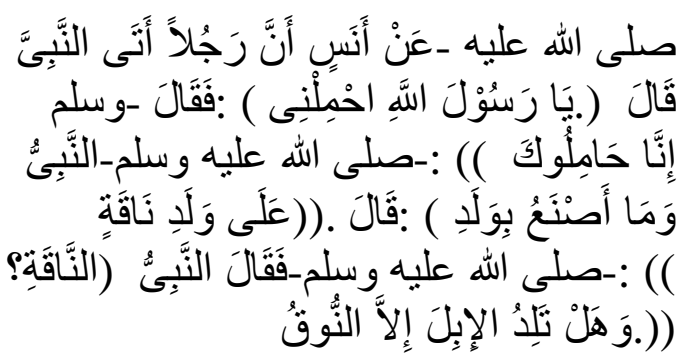

Diriwayatkan dari Anas radhiallahu 'anhu bahwasanya seseorang mendatangi Nabi shallallahu 'alaihi wa sallam. Dia pun berkata, "Ya Rasulullah! Angkatlah saya (ke atas onta)!" Nabi shallallahu 'alaihi wa sallam pun mengatakan, "Sesungguhnya kami akan mengangkatmu ke atas anak onta." Lelaki itu pun berkata, "Apa yang saya lakukan dengan seekor anak onta?" Nabi shallallahu 'alaihi wa sallam bersabda, "Bukankan onta-onta perempuan melahirkan onta-onta?" 
Beliau mencandai orang tersebut dengan menyebut ontanya dengan anak onta. Orang tersebut memahami perkataan beliau sesuai zahirnya, tetapi bukankah semua onta yang ada adalah anak-anak dari ibu onta?

$\underline{\text { Hadits } 2}$

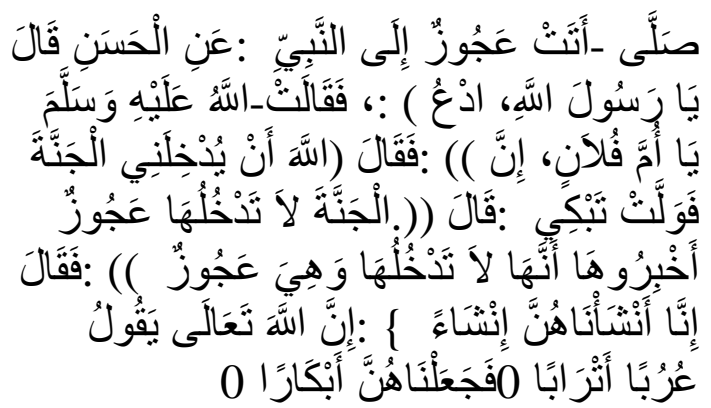

Diriwayatkan dari Al-Hasan radhiallahu 'anhu, dia berkata, "Seorang nenek tua mendatangi Nabi shallallahu alaihi wa sallam. Nenek itu pun berkata, 'Ya Rasulullah! Berdoalah kepada Allah agar Dia memasukkanku ke dalam surga!' Beliau pun mengatakan, 'Wahai Ibu si Anu! Sesungguhnya surga tidak dimasuki oleh nenek tua.' Nenek tua itu pun pergi sambil menangis. Beliau pun mengatakan, 'Kabarkanlah kepadanya bahwasanya wanita tersebut tidak akan masuk surga dalam keadaan seperti nenek tua. Sesungguhnya Allah ta'ala mengatakan: (35) Sesungguhnya kami menciptakan mereka (Bidadari-bidadari) dengan langsung. (36) Dan kami jadikan mereka gadis-gadis perawan. (37) Penuh cinta lagi sebaya umurnya." (QS AlWaqi'ah) ${ }^{6}$

Jika kita perhatikan hadits-hadits di atas, maka kita mendapatkan bahwa Rasulullah shallallahu 'alaihi wa sallam bercanda pada beberapa keadaan tertentu, tetapi canda beliau tidak mengandung kedustaan dan selalu benar.

Orang yang terlalu serius dan selalu terlihat tegang dan kaku, kehidupannya akan terasa sangat penat dan suntuk. Orang jenis ini seharusnya memasukkan canda di dalam hidupnya sehingga terhindar dari pengaruh buruk tersebut. Sebaliknya orang yang terlalu sering bercanda, maka sebaiknya dia belajar untuk dapat melatih lisannya agar bisa terbiasa diam dan hanya berbicara pada hal-hal yang bermanfaat saja.

Seorang penyair terkenal, Abul-Fath AlBusti rahimahullah pernah mengatakan:

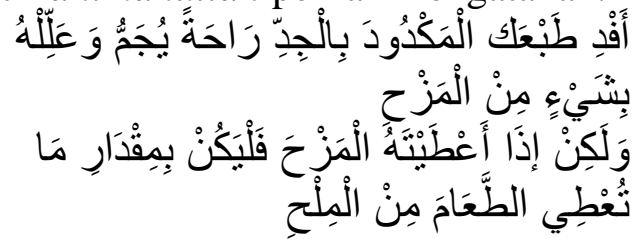

Berikanlah istirahat pada tabiat kerasmu yang serius

Dirilekskan dulu dan hiasilah dengan sedikit canda

Tetapi jika engkau berikan canda

kepadanya, jadikanlah ia

Seperti kadar engkau memasukkan garam pada makanan

Layaknya makanan, apabila tidak diberi garam maka dia akan terasa hambar. Akan tetapi, jika terlalu banyak diberikan garam, maka tidak akan enak untuk dimakan. Sesuatu yang berlebihlebihan, kebanyakan akan membawa dampak buruk. Sama halnya dengan bercanda dan tertawa. Apabila terlalu sering bercanda dan tertawa, maka akan mengakibatkan banyak keburukan. Bercanda atau memicu orang tertawa dan tersenyum umumnya dilakukan secara verbal atau lisan, sehingga secara keseluruhan agama memberi petunjuk agar kita menjaga dan memelihara lidah atau perkataan. merupakan paling banyak aktivitas verbal (

\section{Adab dan Fungsi Humor}

\section{Adab Humor (bercanda)}

Dalam bercanda sudah sepantasnya kita memperhatikan adab-adab sebagai berikut:

a. Tidak boleh ada kedustaan di dalam canda tersebut. Sebagaimana Rasulullah shallallahu 'alaihi wa sallam bersabda: 


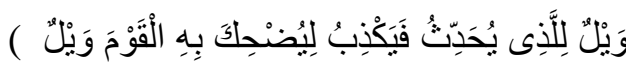

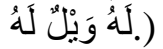

"Celakalah orang yang berbicara kemudian dia berdusta agar suatu kaum tertawa karenanya. Kecelakaan untuknya. Kecelakaan untuknya."

Di zaman sekarang ini, banyak orang yang bekerja sebagai pelawak. Kebanyakan mereka tidak bisa menjaga lisannya dari kedustaan. Oleh karena itu, sebaiknya mereka segera mencari pekerjaan lain yang benar-benar terhindar dari hal yang diharamkan. Begitu pula kepada para muballigh yang gemar membuat orang tertawa, sudah sepantasnya isi ceramahnya jangan mengada-ada, harus ilmiah dan memiliki rujukan yang bisa dipertanggungjawabkan.

b. Tidak boleh ada unsur penghinaan atau pelecehan terhadap agama Islam

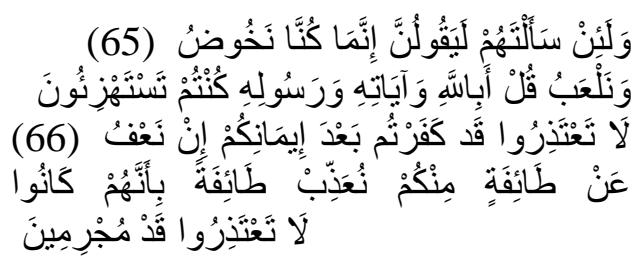

“ (65) Dan jika kamu tanyakan kepada mereka (tentang apa yang mereka lakukan itu), tentulah mereka akan menjawab, "Sesungguhnya kami hanyalah bersenda gurau dan bermain-main saja." Katakanlah: "Apakah dengan Allah, ayat-ayat-Nya dan rasul-Nya kamu selalu berolok-olok?" (66) Tidak usah kamu minta maaf, Karena kamu kafir sesudah beriman. jika kami memaafkan segolongan kamu (lantaran mereka taubat), niscaya kami akan mengazab golongan (yang lain) disebabkan mereka adalah orang-orang yang selalu berbuat dosa." (QS At-Taubah : 65-66).
Kini banyak orang yang suka mengejek ajaran agama Islam dan menjadikannya sebagai bahan lelucon. Sebagai contoh: penghinaan terhadap jenggot dan mengatakan orang yang memanjangkan jenggotnya seperti kambing, penghinaan terhadap jilbab dan mengatakan itu hanya pakaian orang gurun, penghinaan terhadap cadar dan mengatakan bahwa itu ciri-ciri teroris, penghinaan terhadap orang yang tidak isbal (mengenakan kain di bawah mata kaki) dan mengatakan bahwa orang itu kebanjiran dan lain-lain.

Berdasarkan ayat di atas orang yang menghina ajaran Islam terancam untuk keluar dari agama Islam, disadari maupun tidak. Oleh karena itu, jangan sampai kita menganggap remeh permasalahan-permasalahan seperti ini.

c. Tidak boleh ada unsur ghibah dan peremehan terhadap seseorang, suku atau bangsa tertentu

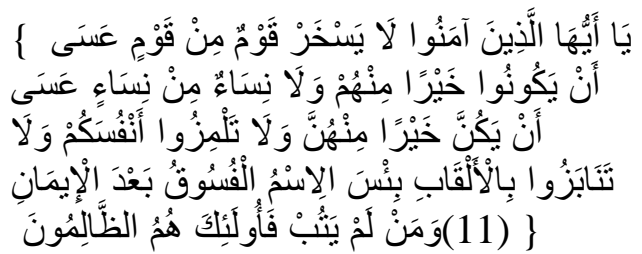
Hai orang-orang yang beriman, janganlah sekumpulan orang lakilaki merendahkan kumpulan yang lain, boleh jadi yang ditertawakan itu lebih baik dari mereka. dan jangan pula sekumpulan perempuan merendahkan kumpulan lainnya, boleh jadi yang direndahkan itu lebih baik. dan janganlah suka mencela dirimu sendiridan jangan memanggil dengan gelaran yang mengandung ejekan. seburuk-buruk panggilan adalah (panggilan) yang buruk sesudah iman dan barangsiapa yang tidak bertobat, Maka mereka Itulah orang-orang yang zalim. (QS Al-Hujurat: 11)

d. Tidak boleh mengambil barang orang lain, meskipun bercanda

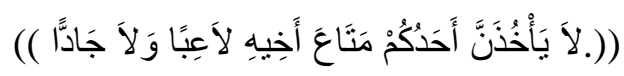


"Tidak boleh seorang dari kalian mengambil barang saudaranya, baik bercanda maupun serius."

Meskipun bercanda, mengambil barang teman dengan tujuan menyembunyikan dan membuat dia bingung, hal tersebut tidak diperkenankan di dalam agama Islam.

e. Tidak boleh menakut-nakuti orang lain.

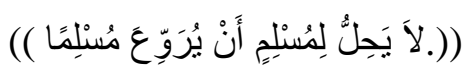

"Tidak halal bagi seorang muslim menakut-nakuti muslim yang lain."

f. Tidak boleh menghabiskan waktu hanya untuk bercanda

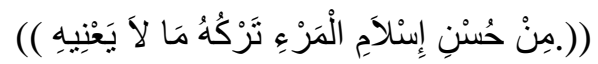

"Di antara tanda baiknya keislaman seseorang adalah dia meninggalkan yang tidak bermanfaat baginya."

g. Tidak boleh berbicara atau melakukan hal-hal yang melanggar syariat, seperti: menyebutkan ciri-ciri wanita yang tidak halal baginya kepada orang lain, menipu, melaknat dll.

h. Hendaknya anda tidak memperbanyak canda hingga menjadi tabiatmu, dan jatuhlah wibawamu dan akibatnya kamu dipermainkan oleh orang lain

\section{Fungsi Humor}

Humor memiliki banyak bentuk dan variasi. Hal ini tergantung pada kreativitas pencipta humor dalam menciptakan humor bagi penikmatnya. Interaksi antara pencipta dan penikmat humor ternyata dapat diwujudkan dalam berbagai bentuk dengan berbagai fungsi yang berbeda-beda. Hal tersebut tergantung pada konteks, penutu, lawan tutur, dan topik pembicaraan antara pencipta humor dan penikmat humor. Fungsi humor dalam kehidupan sangat bervariasi tergantung pada tempat, suasana, dan waktu terjadinya komuni- kasi antara pencipta humor dengan penikmat humor.

Rohmadi (2009:259-281) mendeskripsikan fungsi humor secara umum dalam kehidupan sebagai berikut:

a. Humor berfungsi sebagai media rekreatif

Apa yang dikatakan Stolzt, dalam teori advertsity quotient (ketahanmalangan) sesungguhnya mengajarkan bagaimana manusia dapat menjadi mahluk yang kuat dalam menghadapi kesulitan dan penderitaan sehingga mampu mengatasinya untuk menjadi orang sukses (Rakhmat, 2004:125). Jika kita simak kehidupan masyarakat saat ini yang semuanya serba ingin cepat, ingin yang terbaik dengan megandalkan jalan pintas, tentu saja tidak gamapang menumbuhkan sikap ketangguhan hidup, tahan banting, seperti yang direkomendasikan Stolzt. Sebaliknya, ketika individu selalu membentur kegagalan demi kegagalan dan tak mampu mengembangkan sikap hidup optimistik, maka jadilah ia orang yang frustasi dan pesimistik.

Pada prinsipnya setiap orang memiliki sense of humor yang terbangun dalam dirinya. Humor memainkan peran penting dalam menjaga keseimbangan hidup manusia dalam menghadapi goncangan kesedihan untuk bangkit menjadi kegembiraan.

b. Humor berfungsi sebagai media hiburan masyarakat

Mengacu pada pentingnya humor tersebut di atas, maka sangat perlu keberadaan tempat-tempat hiburan yang terjangkau oleh rakyat, tempat-tempat dimana orang bisa menikmati humor tanpa harus merogoh kantong yang memang sudah tipis. Oleh karenanya, di masa lalu banyak sekali keseniankesenian rakyat yang menyelipkan humor-humor segar yang ringan dan lucu hingga humor satir yang pahit getir. 


\begin{abstract}
c. Humor berfungsi untuk mempengaruhi

Humor dapat berfungsi sebagai alat untuk mempengaruhi lawan tutur dalam berbagai situasi, seperti bidang hukum, politik ekonomi, pendidikan, dan lain sebagainya.
\end{abstract}

d. Humor berfungsi untuk mengkritik

Humor dapat berfungsi untuk mengkritik penikmat humor. Hal ini biasanya digunakan berbagai situasi komunikasi yang diciptakan pencipta dan penikmat humor. Pencipta humor dapat menganalisis wacana humor tersebut secara mandiri atau pun bersama-sama.

e. Humor berfungsi sebagai bentuk ekspresi diri dan eksistensi diri

Humor dapat berfungsi sebagai bentuk ekspresi diri bagi para seniman untuk mengekspresikan perasaannya dalam bentuk gambar, lukisan dan sebagainya.

f. Humor berfungsi sebagai alat untuk iklan

Humor dapat berfungsi sebagi alat untuk iklan. Iklan berarti mempromosikan barang, surat, kegiatan, dan lainnya untuk dimiliki atau diikuti oleh penikmat humornya. Iklan itu dpat dilakukan oleh pencipta humor atau penikmat humor sendiri dalam berbagai konteks.

g. Humor berfungsi sebagai media penalaran

Humor dapat berfungsi sebagi media penalaran dalam berkomunikasi. Humor dapat berfungsi sebagai media atau strategi dalam pembelajaran, diskusi, dan aktivitas lainya daam konteks tertentu.

h. Humor berfungsi sebagai pengasah otak
Humor berfungsi sebagai pengasah otak. Artinya, humor dapat dijadikan latihan untuk mengasah otak melalui tebak-tebakan humor dan keerdasan berpikir seseorang.

i. Humor berfungsi sebagai alat plesetan

Hal ini dapat dilakukan oleh pencipta humor dalam berbagai situasi dan bentuk. Pencipta humor melakukan pelesetan dalam ranah linguistik, seperti pada tataran fonologis dan morfologis.

j. Humor berfungsi sebagai motivasi diri

Humor dapat berfungsi sebagai alat untuk memotivasi diri dan orang lain. Hidup harus dihadapi dengan senyum, begitu kata orang bijak. Lahirnya humor dalam cerita lisan di dalam tradisi mana pun, boleh jadi ditujukan untuk hal demikian. Dalam kebudayaan Sunda ada si Kabayan, kebudayaan Jawa Si Pandir dan sebagainya.

Menyadur pendapat Rohmadi, Marwan (2013) menjelaskan fungsi humor sufi dalam kehidupan adalah sebagai berikut:

a. Sebagai media penalaran

Humor sufi berfungsi sebagai media penalaran dan mengasah otak, seperti dalam pembelajaran, diskusi, pembicaraan-pembicaraan yang santai dan berbobot.

b. Sebagai motivasi diri

Humor sufi dapat dijadikan memotivasi diri dan orang lain untuk melakukan perbuatan-perbuatan yang baik dan bermanfaat. Setelah membaca humor sufi, diharapkan orang semakin dekat dengan Tuhan dan meningkatkan amal shalehnya sebagai bekal di akhirat.

c. Untuk mengkritik atau mengajak berpikir

Sebagimana dikatakan oleh Derk (1980:13) bahwa humor bukan hanya mengundang respon emosional, namun juga menstimulasi seseorang berpikir kritis dan merenungi kandungannya. Kisah seorang raja dengan rakyatnya 
dan pengalaman spritual seseorang dalam humor sufi memiliki nilai agama yang sangat bermanfaat untuk diingat dan direnungkan, alih-alih sebagai bentuk zikir aqliyah (mengingat Tuhan melalui akal).

d. Media dakwah agama

Selain fungsi yang disebutkan di atas, fungsi utama humor sufi adalah menyampaikan pesan-pesan agama dan risalah para Nabi dan Rasul. Humor sufi tidak kosong kandungan nilai-nilai agama baik yang bersifat fundamental maupun intrumental.

\section{Relasi Humor dan Agama}

Sejauh ini relasi humor dan agama tidak banyak dikaji baik secara teoretis maupun empiris. Relasi kedua hal tersebut hanya terjadi secara kontekstual dan topikal. Maksudnya dalam hal ini kejenakaan atau kelucuan diciptakan dengan memanfaatkan konteks dan topik agama. Sebagaimana kelucuan yang terdapat dalam teks-teks humor sufi. Humor sufi merupakan tipe humor yang memiliki latar dan topik agama. Oleh karena itu, humor sufi memiliki peran sebagai media dakwah ajaran dan pesan-pesan agama, khususnya agama Islam.

Sebagai bentuk ungkapan kegembiraan, tawa yang tidak berlebihan diperbolehkan oleh agama. Bahkan senyum sebagai ekspresi sikap ramah dan baik terhadap seseorang dianjurkan oleh Nabi. Jadi, tawa dan senyum merupakan wujud kebahagiaan dan kesenangan hati yang merupakan fitrah manusia.

Ayat-ayat Al Quran dan Hadis menerangkan setidaknya posisi dan peran manusia memanfaatkan karunia Allah yang telah memberikan keistimewaan nikmat, yakni fitrah manusia memiliki rasa humor sebagai bentuk ungkapan rasa senang dan menangis sebagai wujud rasa sedih.

Mencari makna hidup merupakan hal universal bagi semua manusia yang memiliki keyakinan agama yang kuat (Saroglou, 2002). Agama memberi jawaban secara objektif akan permasalahan manusia. Oleh karena itu banyak lembaga edukasi yang menanamkan karakter agama untuk menggali kebermaknaan hidup. Tawa dan tangis adalah fitrah manusia yang telah diberikan Tuhan kepada manusia.

\section{Kesimpulan}

Humor dan rasa humor adalah bagian dari kehidupan manusia seharihari. Tawa dan senyum adalah wujud dari rasa humor yang dikaruniai Allah swt sebagai fitrah manusia. Agama Islam menganjurkan untuk menyedikitkan tawa agar manusia tidak terlena dalam kehidupan dunia. Namun demikian memperbanyak senyum sebagai bentuk sikap ramah dan baik untuk menyenangkan orang lain adalah sebuah perbuatan yang baik dan berpahala.

Agama adalah pedoman kehidupan yang memberi petunjuk manusia agar memperoleh kebahagiaan sebenarnya di akhirat. Segala aktivitas kehidupan manusia sewajarnya sejalan dengan aturan-aturan yang telah digariskan dalam Al Quran dan hadis. Langkah pertama gemar menyenangkan orang lain adalah menebar senyuman.

Orang yang mengenal agama akan memiliki sense of humor yang positif, karena selain dapat membuat orang lain tersenyum atau tertawa, namun juga menyuruh orang berpikir kritis, mawas diri, dan merenung (tafakur) pesan dari humor dan canda tersebut. Intinya dengan humor positif, boleh jadi orang akan lebih mengenal Tuhan-Nya.

\section{Daftar Pustaka}

Al Qur'an dan Terjemahnya. 2004. Departemen Agama (Depag) RI. Madinah Munawwarah: Komplek Percetakan Quranul Karim milik Raja Fahd. 
Al-Qarni , 'Aidh. 2005. Ibtasim. Riyadh: Maktabah 'Ubaikan.

Derks, Peter. 1980. Psychology of Humor: An Integrative Approach. College of William and Mary

Goldstein, Jeffrey H, \& McGhee, Paul E. (ed). 1972. The Psychology of Humor. New York: Academic Pess.

Haryanto, R \&Suyasa, P.T.Y.S. 2007. Persepsi terhadap Job caractheristic model,

psychological well-being, and perpformance (Studi pada Karyawan PT. X) . Phronesis 9.

Martin, R. 2003. Sense of Humor. In S. J. \& C.R. Snyder (Eds) Positive Psychological

Asssesment. A Handbook of Models and Measures. Washington DC: American Psychological Association.

Marwan, Iwan. 2008. Penggunaan Pelesetan dalam Wacana Humor: Analisis Struktur

dan Makna. Tesis tidak diterbitkan. Bandung: SPS Universitas Pendidikan Indonesia.

Rakhmat, Jalaluddin. 2004. Retorika. Bandung: PT. Remaja Rodakarya.

Rohmadi, Muhammad. 2009. Wacana Humor dalam Bahasa Indonesia: Analisis

Tekstual dan Kontekstual. Disertasi tidak diterbitkan. Yogyakarta: PPS Universitas Gadjah Mada

Wilson, C.P. 1979. Jokes: Form, Content, Use and Function. London: Academic Press. 